\title{
Metakognisi Siswa Operasional Konkret dalam Pemecahan Masalah Matematika
}

\author{
Mu'jizatin Fadiana $^{1 \bowtie}$ dan Andriani ${ }^{2}$ \\ ${ }^{1,2}$ Prodi Pendidikan Matematika, Universitas PGRI Ronggolawe
}

\section{Info Artikel}

Sejarah Artikel:

Diterima 2 Apr 2021

Direvisi 28 Apr 2021

Disetujui 30 Apr 2021

\section{Keywords:}

Metacognition,

Mathematical Problems

Paper type:

Research paper

\begin{abstract}
Vocational High School students should have their cognitive development stage in formal operations. However, there are still vocational high school students whose cognitive development stages are in concrete operations. The purpose of this study was to determine the students' concrete operational metacognition in solving mathematical problems. The research method used is descriptive qualitative. The research subjects were two students who were taken using purposive sampling. The research instrument used was the logical thinking ability test, problem-solving tests and metacognition interview guidelines. The data analysis stages used were examining all data, classifying the level of students' logical thinking abilities, selecting concrete operational students to be used as research subjects, reviewing the results of concrete operational student metacognition work in solving mathematical problems, verifying data and data sources that had been classified and transcribed in presentation or exposure to data. The results showed that concrete operational students carried out cognitive regulation in the step of understanding problems, implementing plans and re-examining solutions that had been produced. The metacognition skill component appeared at all three steps. Only the step of making a plan that does not occur properly regulation of cognition. It can be concluded that concrete operational students who are in grade X of vocational high school have good metacognition skills, but are weak in problem solving abilities.
\end{abstract}

\begin{abstract}
Abstrak
Siswa jenjang Sekolah Menengah Kejuruan (SMK) seharusnya tahap perkembangan kognitifnya berada pada operasional formal. Namun masih dijumpai siswa jenjang SMK yang tahap perkembangan kognitifnya berada pada operasional konkret. Tujuan penelitian ini adalah untuk mengetahui metakognisi siswa operasional konkret dalam memecahkan masalah matematika. Metode penelitian yang digunakan adalah deskriptif kualitatif . Subjek penelitian sebanyak dua siswa yang diambil dengan menggunakan purposive sampling. Instrumen penelitian yang digunakan adalah Tes Kemampuan Berpikir Logis (TKBL), tes pemecahan masalah dan pedoman wawancara metakognisi. Tahapan analisis data yang digunakan adalah meneliti semua data, membuat klasifikasi level kemampuan berpikir logis siswa, memilih siswa operasional konkret yang akan digunakan sebagai subjek penelitian, meninjau hasil kerja metakognisi siswa operasional konkret dalam menyelesaikan masalah matematis, memverifikasi data dan sumber data yang telah diklasifikasikan dan ditranskripsi dalam presentasi atau paparan data. Hasil penelitian menunjukkan bahwa siswa operasional konkret melakukan regulasi kognisi pada langkah memahami masalah, melaksanakan rencana dan memeriksa kembali solusi yang telah dihasilkan. Komponen ketrampilan metakognisi muncul pada ketiga langkah tersebut. Hanya langkah menyusun rencana saja yang tidak terjadi regulasi kognisi dengan baik. Dapat disimpulkan bahwa siswa operasional konkret yang berada di Kelas X SMK mempunyai ketrampilan metakognisi yang baik, namun lemah dalam kemampuan pemecahan masalah.
\end{abstract}

(C) 2021 Universitas Muria Kudus

\begin{tabular}{lc}
\hline Alamat korespondensi: & p-ISSN 2615-4196 \\
Program Studi Pendidikan Matematika & e-ISSN 2615-4072 \\
Fakultas Keguruan dan Ilmu Pendidikan Universitas Muria Kudus & \\
Kampus UMK Gondangmanis, Bae Kudus Gd. L. It I PO. BOX 53 Kudus & \\
Tlp (0291) 438229 ex.147 Fax. (0291) 437198 & \\
E-mail: mujizatin000@gmail.com &
\end{tabular}




\section{PENDAHULUAN}

Salah satu kemampuan yang harus dimiliki siswa dalam pembelajaran matematika adalah kemampuan pemecahan masalah (Nuritasari \& Anjarani, 2019; Surya, Putri \& Mukhtar, 2017). Kemampuan pemecahan masalah merupakan kemampuan berpikir tingkat tinggi (Abdullah, Abidin \& Ali, 2015; Nadapdap \& Istiyono, 2017), dimana kemampuan tersebut merupakan tujuan utama dalam pembelajaran matematika saat ini sehingga harus diberikan, dilatih, dan dibiasakan oleh guru kepada siswa (Minarni, Napitupulu \& Husein, 2016; Yenita Roza \& Eliya Astika, 2019). Dalam kurikulum matematika, pemecahan masalah merupakan bagian yang sangat penting. Hal ini disebabkan, siswa akan memperoleh pengalaman menggunakan pengetahuan dan keterampilan yang selama ini dibutuhkan untuk diterapkan pada pemecahan masalah yang tidak ruti (Widodo \& Turmudi, 2017). Banyak metode pemecahan masalah. Salah satu metode yang dapat digunakan untuk menyelesaikan masalah matematika adalah metode Polya (1973) yang terdiri dari pemahaman masalah, perencanaan pemecahan masalah, pelaksanaan rencana, dan pengecekan jawaban yang telah disusun oleh siswa.

Beberapa hasil penelitian menunjukkan bahwa kemampuan pemecahan masalah matematika sebagian besar siswa di Indonesia, baik di tingkat sekolah menengah maupun perguruan tinggi, masih tergolong rendah (Akbar dkk, 2017; Ulya, 2015). Banyak faktor yang menyebabkan kemampuan siswa dalam menyelesaikan masalah matematika belum optimal, di antaranya adalah strategi pembelajaran yang digunakan (Effendi 2012; Puadi \& Habibie 2018), perangkat pembelajaran yang digunakan (Hasibuan, Saragih \& Amry 2018; Siagian, Saragih \& Sinaga 2019), kemampuan guru dalam memberikan pendampingan individu belum maksimal (Annamma 2015; Elstad \& Christophersen 2017) dan tingkat perkembangan kognitif siswa belum mencapai tahap formal, sehingga siswa kesulitan memahami materi matematika yang abstrak (Abdullah \& Zakaria 2013). Kemampuan siswa dalam pemecahan masalah matematika berkaitan erat dengan tingkat perkembangan kognitif mereka.

Terdapat lima kemampuan yang harus dimiliki oleh siswa agar bisa menyelesaikan suatu masalah yaitu kemampuan tentang konsep matematika, kemampuan tentang keterampilan algoritma matematika, kemampuan proses bermatematika, kemampuan untuk bersikap positif terhadap matematika, dan kemampuan metakognitif (Anggo 2011). Kesuksesan seseorang dalam memecahkan masalah antara lain bergantung pada kesadarannya tentang apa yang ia ketahui dan bagaimana ia melakukannya (Suherman 2011). Kesadaran ini dikenal dengan istilah metakognisi. Metakognisi merupakan pengetahuan dan kesadaran seseorang tentang proses kognitifnya sendiri (Sugiyono 2015). Dengan menggunakan metakognisi ini, seseorang bisa mengatur kondisi dan memilih strategi yang cocok untuk meningkatkan kinerja kognitifnya dalam memecahkan suatu masalah (Desoete 2009; Desoete, Roeyers \& Huylebroeck 2006). Seseorang memecahkan masalah dengan menggunakan metakognisi, yaitu merencanakan langkah-langkah untuk dikerjakan sebelum memecahkan masalah, memantau dirinya sendiri selama bekerja, mengikuti rencana, dan mengevaluasi diri setelah menyelesaikan pekerjaan. Metakognisi membuat siswa menggunakan pengetahuan yang tersedia dengan strateginya sendiri. Keterampilan metakognitif diperlukan terutama untuk memeriksa apa yang telah diketahui dan apa yang belum diketahui, memantau pembelajaran, dan merencanakan untuk mempelajari keterampilan baru (Aminah \& Sabandar 2011) .

Kemampuan metakognisi bisa muncul pada usia yang sangat muda (Balcomb \& Gerken 2008). Proses perkembangan kemampuan metakognisi ini terus berjalan sesuai perkembangan usia anak. Metakognisi berkembang seiring usia dan juga dipengaruhi oleh latihan (Larkin 2006). Interaksi satu sama lain dapat memberikan stimulus yang diperlukan oleh individu untuk menjadi lebih menyadari proses kognitif mereka. Proses metakognisi ada di setiap perkembangan kognitif individu, sedangkan tingkat perkembangan kognitif individu dapat dilihat dari kemampuan berpikir logis mereka (Fadiana, Amin, Lukito, Wardhono, et al. 2019). Sehingga, kemampuan metakognisi juga dipengaruhi oleh tingkat kemampuan berpikir logis.

Berpikir adalah kegiatan menemukan pengetahuan yang benar. Berpikir logis merupakan aktivitas berpikir menurut pola tertentu; pola logis. Logika dapat diartikan secara luas sebagai investigasi untuk berpikir valid. Berpikir logis adalah berpikir berdasarkan alasan, bukan perasaan. Penalaran adalah suatu proses berpikir untuk menarik suatu kesimpulan dan memiliki ciri tertentu, aktivitas berpikir tidak didasarkan pada penalaran seperti intuisi, tetapi berdasarkan pola tertentu. Berpikir logis 
merupakan berpikir dalam pola sebab-akibat, yang berarti berpikir berurutan (Fadiana, Amin, Lukito \& Warli 2019). Selain itu, berpikir logis dapat diartikan sebagai berpikir yang mengikuti kaidah inferensi logis, dan merupakan keterampilan berpikir kognitif tingkat tinggi (Fadiana, Amin, Lukito, Wardhono, et al. 2019). Berpikir logis adalah aktivitas yang seseorang mempertimbangkan, nalar, dan bentuk berpikirnya dinamis dalam proses pemahaman untuk mengklaim realitas objektif dari pengetahuan rasional(Othman, Hussain \& Nikman 2010). Pemikiran logis mengikuti urutan pemikiran atau gagasan, mempertimbangkan apa yang terjadi dan memprediksi sesuatu di masa depan: jika ini terjadi, maka yang lain juga akan melakukannya (Su, Ricci \& Mnatsakanian 2016).

Siswa Sekolah Menengah Kejuruan (SMK) berusia di atas 12 tahun, dimana menurut Piaget perkembangan kognitif mereka berada pada tahap terakhir dari kognitif, yaitu kognitif formal (Ojose 2015). Perkembangan ini bisa dilihat dari kemampuan siswa dalam berpikir logis, berfikir teoritis formal berpikir berdasarkan proposisi dan hipotesis, dapat menyimpulkan dari apa yang dapat diamati pada saat itu, dan cara berpikir abstrak mulai dipahami (Moore 2012; Syahbana 2012). Seseorang yang berada tahap berfikir formal, umumnya mampu berpikir secara abstrak dalam penalaran klasifikasi, penalaran konservasi, penalaran teoritis, penalaran kombinasi, penalaran proporsional, penalaran fungsional, variabel pengendali, penalaran analogi, penalaran proposisional, penalaran korelasional, penalaran probabilitas (Fadiana et al. 2021; Kincal \& Yazgan 2010).

Namun, berdasarkan hasil pra penelitian, masih banyak siswa jenjang sekolah menengah kejuruan (SMK) yang berada pada tahap operasional konkret. Penelitian ini hendak meneliti tentang pengetahuan dan kesadaran siswa operasional konkret jenjang SMK tentang proses kognitifnya. Siswa SMK secara teori seharusnya berada pada tahap operasional formal, namun kenyataannya mereka masih berada pada tahap operasional konkret. Bagaimana kesadaran mereka tentang proses kognitifnya dalam menyelesaikan masalah matematika? Faktor-faktor apa saja yang mempengaruhi proses metakognisi mereka? Dengan mengetahui kemampuan metakognisi yang baik dalam memecahkan masalah, maka akan memberikan dampak yang baik pula pada proses belajar dan prestasi mereka (Omrod, 2009). Sehingga, semakin siswa mengetahui tentang proses berpikir dan belajar yaitu semakin tinggi kesadaran metakognisi mereka maka akan semakin baik proses belajar dan prestasi dicapai. Schraw (1998) membagi metakognisi menjadi dua komponen, knowledge of cognition (pengetahuan kognisi) dan regulation of cognition (pengaturan kognisi). Knowledge of cognition meliputi; pengetahuan deklaratif, pengetahuan prosedural, dan pengetahuan kondisional. Sedangkan regulasi kognisi meliputi; planning, monitoring dan evaluating. Dalam penelitian ini akan diteliti tentang regulasi kognisi, yang terdiri atas tiga komponen, yaitu; perencanaan (planning), pemantauan (monitoring), dan evaluasi (evaluating).

\section{METODE PENELITIAN}

Berdasarkan permasalahan yang akan diteliti, jenis penelitian ini termasuk dalam penelitian kualitatif jenis studi. Penelitian deskriptif kualitatif bertujuan untuk mengungkap peristiwa atau fakta, keadaan, fenomena, variabel, dan keadaan yang terjadi selama penelitian dengan menyajikan apa yang terjadi. Berkaitan dengan hal tersebut, penelitian ini bermaksud untuk mendeskripsikan metakognisi siswa operasional konkret dalam memecahkan maslah matematika.

Subjek penelitian ini adalah dua siswa kelas X SMK Negeri 1 Tuban jurusan kimia industri semester genap tahun pelajaran 2019/2020 yang diambil dengan teknik purposive sampling. Purposive sampling adalah pengambilan sampel yang dipilih secara cermat sehingga relevan dengan desain penelitian (Creswell, 2012). Subjek yang akan digunakan dalam penelitian dipastikan harus memiliki perkembangan kognitif yang konkret.

Dalam penelitian ini peneliti bertindak sebagai instrumen utama. Selain itu, dalam penelitian ini instrumen pendukung yang digunakan adalah Tes Kemampuan Berpikir Logis (TKBL), tes pemecahan masalah matematis dan pedoman wawancara untuk menggali metakognisi siswa. Tes kemampuan berpikir logis bertujuan untuk mengkonfirmasi perkembangan kognitif seseorang (Inhelder \& Piaget, 1964; Leongson \& Limjap, 2003). Dalam penelitian ini, TKBL mengadopsi dari Fadiana (2019) yang terdiri atas indikator konservasi, penalaran korelasional, penalaran proporsional, variabel pengontrol, penalaran probabilistik dan penalaran kombinatorik. Terdapat 12 item soal berbentuk soal pilihan ganda yang menyajikan pertanyaan dan kemungkinan jawaban beserta pilihan alasan dibalik jawaban. Terdapat gambar 
yang disertakan pada setiap butir soal untuk memvisualkan masalah. Setiap butir soal yang jawabannya benar diberikan skor 1. Apabila jawaban salah atau tidak menjawab diberikan skor 0. Sehingga skor maksimum adalah 12 dan skor minimum adalah 0. Selanjutnya, skor yang diperoleh diklasifikasikan sebagai berikut; skor 0-4 dikelompokkan pada tahap operasional konkret, skor 5-7 adalah tahap transisional, dan skor 8-12 termasuk tahap operasional formal (Bunce \& Hutchinson 1993).

Instrumen tes pemecahan masalah bertujuan untuk mengetahui kemampuan siswa dalam menyelesaikan masalah matematika materi barisan. Dengan menyelesaikan soal barisan, siswa harus mengungkapkan apa yang ada di benaknya untuk dituliskan pada lembar jawaban yang telah disediakan. Terdapat dua masalah dalam instrumen tes pemecahan masalah, antara lain sebagai berikut:

\section{Masalah I: Masalah Ruang Pertunjukan}

Dalam ruang pertunjukan, baris paling depan tersedia 15 kursi. Baris dibelakangnya selalu tersedia 3 kursi lebih banyak dari baris di depannya. Jika pada ruang itu tersedia 10 baris, hitung banyak kursi di ruang pertunjukan!

Masalah II: Masalah Argo Taksi

Misalkan Anda seorang penumpang taksi dan Anda harus membayar biaya buka pintu sebesar Rp.16.000,- dan argo Rp. 4000/km. Berapakah biaya yang harus Anda keluarkan jika perjalanan Anda sejauh $15 \mathrm{~km}$ ?

Untuk mendapatkan data penelitian tentang metakognisi siswa operasional konkret, siswa diminta untuk menyampaikan apa yang mereka pikirkan saat menyelesaikan masalah matematika, kemudian diwawancara dengan menggunakan pedoman wawancara semi terstruktur tentang ketrampilan metakognisi. Data yang diperoleh pada saat wawancara direkam menggunakan alat perekam. Dalam hal ini, metode yang digunakan untuk mengumpulkan data adalah think aloud. Think aloud adalah teknikdimana subjek diminta untuk menyuarakan pemikirannya selama pemecahan masalah dan meminta dia untuk mengulang jika ada sesuatu yang perlu dikatakan selama proses pemecahan masalah, dalam hal ini memungkinkan subjek untuk mengatakan sesuatu atau apa yang dia pikirkan.

Tahapan analisis data yang telah diperoleh dilakukan dengan (1) memeriksa semua data yang dikumpulkan dari berbagai sumber, (2) membuat klasifikasi kognitif jenis siswa, yaitu operasional konkret, transisional, dan operasional formal, (3) memilih siswa operasional konkret untuk dijadikan subjek penelitian, (4) mereview karya konkret siswa dalam menyelesaikan soal pemecahan masalah matematika, (5) memverifikasi data dan sumber data yang telah diklasifikasikan dan ditranskripsikan dalam penyajian atau pemaparan data (Miles, Huberman \& Saldana 2014).

\section{HASIL DAN PEMBAHASAN}

Penentuan subjek penelitian diawali dengan melakukan tes kemampuan berpikir logis pada siswa Kelas X-A SMK Negeri I Tuban jurusan kimia industri. Tes ini diikuti oleh 30 orang siswa dari jumlah keseluruhan siswa di kelas tersebut adalah 32 siswa. Hasil tes kemampuan berpikir logis menunjukkan bahwa dari 30 siswa yang mengikuti tes (17 siswa perempuan dan 13 siswa laki-laki dengan rentang usia 17-18 tahun), hanya 8 siswa yang kemampuan berpikir logisnya berada pada tahap operasional formal, 14 siswa dalam tahap transisional, dan 8 siswa dalam tahap operasional konkret.

घoperasional formal = transisional a operasional konkret

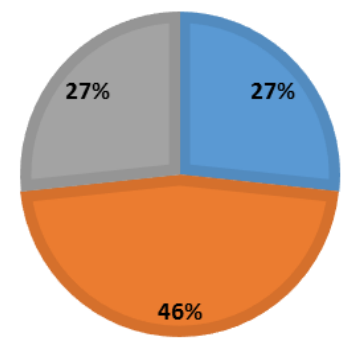

Gambar 1. Hasil Tes Kemampuan Berpikir Logis

Semua siswa yang masuk dalam kategori tahap berpikir konkret diberikan tes pemecahan masalah (TMP) secara tertulis. Berdasarkan hasil pekerjaan TMP tertulis, dipilih dua orang siswa sebagai subjek penelitian untuk diteliti ketrampilan metakognisi selama menyelesaikan TMP. Siswa tersebut diminta untuk menyelesaikan TMP secara think aloud dan menjawab pertanyaan-pertanyaan tentang proses metakognisi melalui wawancara.

\section{Keterampilan Metakognisi Subjek Operasional Konkret Pertama (K1) dalam Menyelesaikan Masalah I}

Subjek K1 pada langkah memahami masalah melaksanakan semua indikator ketrampilan metakognisi planning, antara lain; menentukan apa yang diketahui, menentukan apa yang ditanyakan, dan menyatakan permasalahan 
dengan kalimat sendiri atau bentuk lain. Subjek K1 juga melaksanakan semua indikator ketrampilan metakognisi monitoring, yaitu; meninjau bahwa telah menuliskan semua yang diketahui, meninjau bahwa apa yang ditanyakan dalam soal sudah sesuai dengan yang dimaksud dan meninjau kalimat yang digunakan dalam menyatakan kembali soal tidak bertentangan dengan maksud soal. Sedangkan pada komponen evaluating, subjek K1 melaksanakan semua indikator, yaitu; menyimpulkan bahwa data yang diperoleh tentang apa yang diketahui sudah benar, menyimpulkan bahwa data yang diperoleh tentang apa yang ditanyakan sudah benar dan menyimpulkan bahwa kalimat pernyataan yang telah dibuat sudah sesuai dengan maksud soal.

Pada langkah menyusun rencana, ada beberapa ketrampilan metakognisi planning yang tidak dilakukan oleh K1. K1 tidak mencari hubungan antara yang diketahui dan ditanyakan, tidak mencari strategi lain yang mungkin bisa digunakan. Subjek K1 hanya memiliki satu strategi penyelesaian. Ia tidak merencanakan waktu yang digunakan untuk menyelesaikan soal serta tidak memilih konsep matematika yang sekiranya dapat membantunya untuk menyelesaikan masalah. Pada komponen monitoring subjek K1 tidak memeriksa bahwa strategi yang akan digunakan sudah sesuai atau tidak. Sedangkan pada komponen evaluating, subjek K1 hanya melaksanakan satu dari dua indikator ketrampilan metakognisi yaitu menyimpulkan bahwa strategi penyelesaian yang akan digunakan sudah sesuai.

Langkah ketiga dari langkah-langkah problem solving adalah melaksanakan rencana. Subjek K1 dalam melaksanakan rencana melaksanakan semua indikator pada ketrampilan metakognisi komponen planning, yaitu merencanakan akan menggunakan strategi yang dipilih dan merencanakan akan melakukan perbaikan jika menemukan masalah. Pada komponen monitoring, subjek K1 melaksanakan semua indikator keterampilan metakognisi, yaitu melihat kembali langkah-langkah penyelesaian yang dilakukan sudah benar atau tidak. Sementara pada komponen evaluating subjek K1 melaksanakan semua keterampilan metakognisi, antara lain; menyimpulkan bahwa langkahlangkah penyelesaian yang dilakukan sudah benar, dan menyimpulkan bahwa perbaikan yang dilakukan telah sesuai dan mampu memperbaiki kesalahan.

Subjek K1 dalam memeriksa kembali solusi yang diperoleh tidak melaksanakan semua indikator pada ketrampilan metakognisi komponen planning dan monitoring. Subjek K1 hanya melaksanakan dua indikator pada keterampilan metakognisi komponen evaluating, yaitu menyimpulkan bahwa hasil yang diperoleh sudah benar dan menyimpulkan bahwa strategi yang digunakan efektif menyelesaikan masalah.

Ketrampilan Metakognisi Subjek Operasional Konkret Pertama (K1) dalam Menyelesaikan Masalah II

Subjek K1 pada langkah memahami masalah melaksanakan semua indikator ketrampilan metakognisi komponen planning, antara lain; menentukan apa yang diketahui, menentukan apa yang ditanyakan, dan menyatakan permasalahan dengan kalimat sen diri. Sedangkan, padakomponen monitoring subjek K1 melaksanakan semua indikator ketrampilan metakognisi, yaitu; meninjau bahwa telah menuliskan semua yang diketahui, meninjau bahwa apa yang ditanyakan dalam soal sudah sesuai dengan yang dimaksud dan meninjau kalimat yang digunakan dalam menyatakan kembali soal sudah sesuai dengan maksud soal. Pada komponen evaluating, subjek K1 melaksanakan semua indikator, yaitu; menyimpulkan data yang diperoleh tentang apa yang diketahui sudah benar, menyimpulkan data yang diperoleh tentang apa yang ditanyakan sudah benar dan menyimpulkan bahwa kalimat pernyataan yang telah dibuat sudah sesuai dengan maksud soal.

Pada langkah menyusun rencana, subjek K1 tidak melaksanakan semua indikator ketrampilan metakognisi komponen planning, yaitu; tidak mencari hubungan antara yang diketahui dan ditanyakan, tidak mencari strategi lain yang mungkin bisa digunakan. Subjek K1 hanya memiliki satu strategi penyelesaian. Ia tidak merencanakan waktu yang digunakan untuk menyelesaikan soal dan tidak memilih konsep matematika yang sekiranya dapat membantunya untuk menyelesaikan masalah. Pada komponen monitoring, subjek K1 tidak meninjau kembali apakah strategi yang akan digunakan sudah sesuai atau belum. Sedangkan pada komponen evaluating, subjek K1 hanya melaksanakan satu dari dua indikator keterampilan metakognisi yaitu memutuskan strategi penyelesaian yang akan digunakan sudah sesuai.

Pada langkah melaksanakan rencana problem solving, subjek K1 melaksanakan semua indikator ketrampilan metakognisi komponen planning, yaitu; merencanakan akan menggunakan strategi yang dipilih dan merencanakan akan 
melakukan perbaikan jika menemukan masalah. Pada komponen monitoring, subjek K1 melaksanakan semua indikator ketrampilan metakognisi, yaitu memeriksa kembali apakah langkah-langkah penyelesaian yang dilakukan sudah benar atau tidak. Sedangkan pada komponen evaluating, ia melaksanakan semua ketrampilan metakognisi, antara lain; menyimpulkan bahwa langkah-langkah penyelesaian yang dilakukan sudah benar dan menyimpulkan bahwa perbaikan yang dilakukan telah sesuai dan mampu memperbaiki kesalahan.

Subjek K1 dalam memeriksa kembali solusi yang diperoleh tidak melaksanakan indikator pada keterampilan metakognisi komponen planning dan monitoring. Subjek K1 hanya melaksanakan dua dari tiga indikator pada ketrampilan metakognisi komponen evaluating, yaitu menyimpulkan bahwa hasil yang telah diperoleh sudah benar dan menyimpulkan bahwa strategi yang digunakan efektif menyelesaikan masalah.

\section{Ketrampilan Metakognisi Subjek Operasional Konkret Kedua (K2) dalam Menyelesaikan Masalah I}

Pada langkah memahami masalah, subjek K2 melaksanakan semua indikator ketrampilan metakognisi komponen planning, antara lain; menentukan apa yang diketahui, menentukan apa yang ditanyakan, dan menyatakan permasalahan dengan kalimat sendiri. Pada komponen monitoring subjek K2 melaksanakan semua indikator ketrampilan metakognisi, yaitu; memeriksa bahwa telah menuliskan semua yang diketahui, memeriksa bahwa apa yang ditanyakan dalam soal sudah sesuai dengan yang dimaksud dan memeriksa bahwa kalimat yang digunakan dalam menyatakan kembali soal tidak berlainan dengan maksud soal. Sementara pada komponen evaluating, subjek K2 melaksanakan semua indikator pada ketrampilan metakognisi, antara lain; menyimpulkan bahwa data yang diperoleh tentang apa yang diketahui sudah benar, menyimpulkan bahwa data yang diperoleh tentang apa yang ditanyakan sudah benar dan menyimpulkan bahwa kalimat pernyataan yang telah dibuat sudah sesuai dengan maksud soal.

Subjek K2 pada langkah menyusun rencana, melaksanakan ketrampilan metakognisi komponen planning. Subjek K2 dapat mencari hubungan antara yang diketahui dengan yang ditanyakan. Ia tidak mencari beberapa strategi yang mungkin bisa digunakan. Ia hanya mengetahui satu strategi penyelesaian. Subjek K2 tidak merencanakan waktu yang digunakan untuk menyelesaikan soal dan tidak memilih konsep matematika yang sekiranya dapat membantu untuk menyelesaikan masalah. Pada komponen monitoring, subjek K2 memeriksa kembali bahwa hubungan antara yang diketahui dengan yang ditanyakan sudah sesuai. Namun, subjek K2 tidak meninjau apakah strategi yang akan digunakan sudah sesuai atau tidak. Pada komponen evaluating subjek $\mathrm{K} 2$ hanya melaksanakan satu dari empat indikator pada ketrampilan metakognisi yaitu memutuskan strategi penyelesaian yang akan digunakan sudah sesuai.

Pada langkah melaksanakan rencana, subjek K2 melaksanakan semua indikator pada ketrampilan metakognisi komponen planning. Subjek K2 merencanakan akan menggunakan strategi yang dipilih dan merencanakan akan melakukan perbaikan jika menemukan masalah. Pada komponen monitoring, subjek K2 melaksanakan semua indikator ketrampilan metakognisi, yaitu meninjau apakah langkahlangkah penyelesaian yang dilakukan sudah benar atau tidak. Sedangkan pada komponen evaluating, subjek K2 melaksanakan semua ketrampilan metakognisi. Subjek K2 menyimpulkan bahwa langkah-langkah penyelesaian yang dilakukan sudah benar. Subjek K2 menyimpulkan bahwa perbaikan yang dilakukan telah sesuai dan mampu memperbaiki kesalahan.

Pada langkah memeriksa kembali solusi yang diperoleh, subjek K2 melaksanakan semua indikator ketrampilan metakognisi komponen planning yaitu merencanakan akan memeriksa hasil yang diperoleh. Pada komponen monitoring, subjek K2 tidak memeriksa langkah-langkah pengerjaannya dari awal sampai selesai. Sementara pada komponen evaluating, subjek K2 melaksanakan semua indikator ketrampilan metakognisi. Subjek K2 menyimpulkan bahwa hasil yang diperoleh sudah benar. Ia menyimpulkan bahwa prosedur yang digunakan untuk memeriksa hasil sudah benar dan juga menyimpulkan bahwa strategi yang digunakan efektif menyelesaikan masalah.

\section{Ketrampilan Metakognisi Subjek Operasional Konkret Kedua (K2) dalam Menyelesaikan Masalah II \\ Pada langkah memahami masalah, subjek} K2 melaksanakan semua indikator ketrampilan metakognisi komponen planning. Subjek K2 menentukan apa yang diketahui, menentukan apa yang ditanyakan, dan menyatakan permasalahan dengan kalimat sendiri atau bentuk lain. Pada 
komponen monitoring, subjek K2 melaksanakan semua indikator yaitu; meninjau bahwa ia telah menuliskan semua yang diketahui, meninjau bahwa apa yang ditanyakan dalam soal sudah sesuai dengan yang dimaksud dan meninjau kalimat yang digunakan dalam menyatakan kembali soal tidak bertentangan dengan maksud soal. Sedangkan, pada komponen evaluating, subjek K2 melaksanakan semua indikator ketrampilan metakognisi. Subjek K2 menyimpulkan bahwa data yang diperoleh tentang apa yang diketahui sudah benar, menyimpulkan bahwa data yang diperoleh tentang apa yang ditanyakan sudah benar dan menyimpulkan bahwa kalimat pernyataan yang telah dibuat sudah sesuai dengan maksud soal.

Pada langkah menyusun rencana problem solving, subjek K2 tidak melaksanakan ketrampilan metakognisi komponen planning. Subjek K2 tidak mencari hubungan antara yang diketahui dengan yang ditanyakan, tidak mencari beberapa strategi lain yang mungkin bisa digunakan, hanya menggunakan satu strategi penyelesaian, tidak merencanakan waktu yang digunakan untuk menyelesaikan soal dan tidak memilih konsep matematika yang sekiranya dapat membantu untuk menyelesaikan masalah. Pada komponen monitoring, subjek K2 tidak meninjau apakah strategi yang akan digunakan sudah sesuai atau tidak. Sedangkan pada komponen evaluating, subjek K2 hanya melaksanakan satu indikator, yaitu menyimpulkan strategi penyelesaian yang akan digunakan sudah sesuai.

Pada langkah melaksanakan rencana problem solving, subjek K2 melaksanakan semua indikator ketrampilan metakognisi komponen planning. Subjek K2 merencanakan akan menggunakan strategi yang dipilih dan merencanakan akan melakukan perbaikan jika menemukan masalah. Pada komponen monitoring, subjek K2 melaksanakan semua indikator ketrampilan metakognisi, yaitu memeriksa kembali apakah langkah-langkah penyelesaian yang dilakukan sudah benar atau tidak. Sementara pada komponen evaluating, subjek K2 melaksanakan semua keterampilan metakognisi. Subjek K2 menyimpulkan bahwa langkah-langkah penyelesaian yang dilakukan sudah benar dan menyimpulkan bahwa perbaikan yang dilakukan telah sesuai dan mampu memperbaiki kesalahan.

Subjek K2 dalam memeriksa kembali solusi yang diperoleh, melaksanakan semua indikator pada ketrampilan metakognisi komponen planning. Subjek K2 merencanakan akan memeriksa hasil yang diperoleh. Pada komponen monitoring, subjek K2 tidak memeriksa langkahlangkah pengerjaannya dari awal sampai selesai. Sementara pada komponen evaluating, subjek K2 melaksanakan semua indikator ketrampilan metakognisi. Subjek menyimpulkan bahwa hasil yang diperoleh sudah benar, menyimpulkan bahwa prosedur yang digunakan untuk memeriksa hasil sudah benar dan menyimpulkan bahwa strategi yang digunakan efektif menyelesaikan masalah.

Berdasarkan hasil penelitian, dalam pemecahan masalah matematika subjek operasional konkret tidak melakukan semua regulasi kognisi di setiap langkah pemecahan masalah. Pada langkah memahami masalah, subjek operasional konkret melaksanakan semua indikator dari komponen planning, monitoring dan evaluating. Pada langkah ini, subjek operasional konkret melaksanakan regulasi kognisi dan subjek telah menggunakan pengetahuan deklaratif. Pengetahuan deklaratif adalah pengetahuan seseorang tentang dirinya sendiri sebagai pembelajar dan tentang faktor apa saja yang mempengaruhi performa belajarnya (Schraw 2010). Dengan kata lain, pengetahuan deklaratif adalah pengetahuan tentang sesuatu hal (knowing "about" things). Subjek operasional konkret mampu menentukan, memeriksa kembali dan memutuskan informasi yang diketahui dan apa yang ditanyakan dalam sola pemecahan masalah. Subjek operasional konkret tidak menebak, namun dia telah menggunakan regulasi kognisi. Hal ini berbeda dengan penelitian Phonapichat et al., (2014) yang menyatakan bahwa subjek dengan tingkat kognisi rendah tidak memahami masalah dan kemungkinan besar menebak tanpa menggunakan proses berpikir matematis.

Pada langkah menyusun rencana problem solving, subjek operasional konkret tidak melaksanakan ketrampilan metakognisi komponen planning dan monitoring. Subjek tidak mencari hubungan antara yang diketahui dengan yang ditanyakan, hanya menggunakan satu strategi penyelesaian, tidak merencanakan waktu yang digunakan untuk menyelesaikan soal serta tidak memilih konsep matematika yang sekiranya dapat membantu untuk menyelesaikan masalah.

Pada langkah melaksanakan rencana problem solving, subjek operasional konkret melaksanakan semua indikator ketrampilan metakognisi komponen planning, monitoring dan evaluating. Namun, karena subjek tidak melakukan aktivitas regulasi kognisi pada langkah menyusun rencana, maka ia tidak mampu menyelesaikan masalah dan jawaban subjek tidak tepat. Begitu juga pada langkah memeriksa 
kembali solusi yang diperoleh, subjek telah melakukan regulasi kognisi. Ia melaksanakan semua indikator pada ketrampilan metakognisi komponen planning, monitoring dan evaluating, meskipun solusi yang dihasilkan adalah salah. Hasil penelitian ini sejalan dengan penelitian Phonapichat (2014) yang menyatakan bahwa subjek dengan tingkat kognisi rendah kesulitan dalam memahami kata kunci yang muncul dalam masalah sehingga tidak bisa menafsirkannya menjadi simbol dan solusi pemecahan masalah. Selain itu,juga menyatakan bahwa siswa dengan kemampuan kognitif rendah, baik laki-laki maupun perempuan memiliki langkah-langkah pemecahan masalah yang kurang baik karena tidak dapat menyelesaikan masalah secara tuntas, sehingga tidak mempunyai hasil yang diperoleh.

Subjek operasional konkret melakukan regulasi kognisi pada langkah memahami masalah, melaksanakan rencana dan memeriksa kembali solusi yang telah dihasilkan. Indikator ketrampilan metakognisi muncul pada ketiga langkah tersebut. Hanya langkah menyusun rencana saja yang tidak terjadi regulasi kognisi dengan baik. Hal ini berarti, subjek operasional konkret yang berada di Kelas X SMK mempunyai ketrampilan metakognisi yang baik, namun lemah dalam kemampuan pemecahan masalah. Kelemahan ini nampak pada langkah menyusun rencana. Akibatnya solusi yang diperoleh tidak tepat. Siswa dengan tingkat perkembangan kognitif rendah, yaitu pada tahap operasional konkret, belum tentu ketrampilan metakognisinya juga rendah. Begitu juga sebaliknya, siswa dengan tingkat perkembangan kognitif tinggi juga belum tentu memiliki ketrampilan metakognisi tinggi. Hal ini sejalan dengan penelitian Setyadi (2017) yang menyatakan bahwa siswa yang memiliki kemampuan kognisi lebih tinggi belum tentu memiliki level metakognisi yang lebih tinggi. Namun, hasil penelitian ini berbeda dengan hasil penelitian Mahromah (2013) yang menyatakan bahwa semakin tinggi kemampuan kognisi yang dimiliki siswa, semakin tinggi juga level metakognisi siswa tersebut.

Pola ketrampilan metakognisi dalam pemecahan masalah dari subjek operasional konkret adalah termasuk pola metakognisi primitive problem solving. Siswa dengan kemampuan pemecahan masalah primitive problem solving hanya melibatkan proses monitoring pada saat mengidentifikasi masalah, selanjutnya tidak ada lagi regulation of cognition yang dilibatkan. Pada knowledge of cognition siswa hanya menggunakan declarative knowledge pada saat mengidentikasi masalah dan tidak melibatkan conditional knowledge selama pemecahan masalah. Pola metakognisi primitive problem solving seperti digambarkan pada Gambar 2.

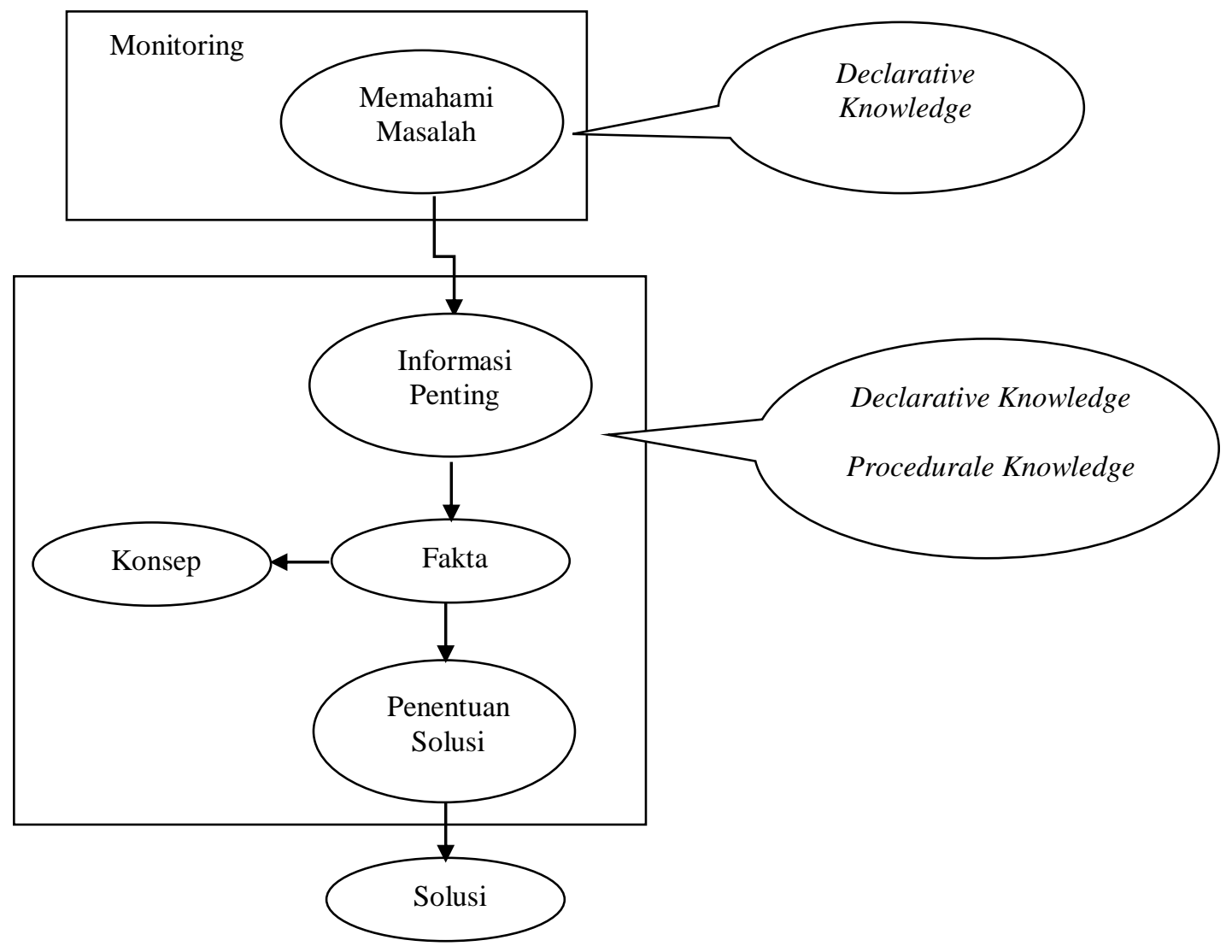




\section{Gambar 2. Pola Metakognisi Primitive Problem Solving}

\section{SIMPULAN}

Siswa jenjang SMK Kelas $\mathrm{X}$ yang tahap perkembangan kognitifnya berada pada tahap operasional konkret melakukan regulasi kognisi pada langkah memahami masalah, melaksanakan rencana dan memeriksa kembali solusi yang telah dihasilkan. Komponen ketrampilan metakognisi yang terdiri atas planning, monitoring dan evaluating muncul pada ketiga langkah tersebut. Hanya langkah menyusun rencana saja yang tidak terjadi regulasi kognisi dengan baik. Sehingga, siswa operasional konkret yang berada di Kelas X SMK mempunyai ketrampilan metakognisi yang baik, namun lemah dalam kemampuan pemecahan masalah. Kelemahan ini nampak pada langkah menyusun rencana. Akibatnya solusi yang diperoleh tidak tepat.

Hasil penelitian ini dapat ditindak lanjuti oleh peneliti selanjutnya untuk meneliti tentang hubungan antara tingkat perkembangan kognitif siswa pada berbagai jenjang pendidikan dengan kemampuan metakognisi siswa. Dimungkinkan, kemampuan metakognisi siswa operasional konkret pada jenjang sekolah dasar dan sekolah menengah pertama berbeda hasilnya dengan kemampuan metakognisi siswa operasional konkret pada jenjang sekolah menengah atas. Selain itu, peneliti selanjutnya juga dapat mengembangkan penelitian tentang korelasi antara tingkat perkembangan kognitif siswa dengan kemampuan pemecahan masalah matematika.

\section{DAFTAR PUSTAKA}

Abdullah, A. H., Abidin, N. L. Z., \& Ali, M. 2015. Analysis of Students' Errors in Solving Higher Order Thinking Skills (HOTS) Problems for the Topic of Fraction. Asian Social Science, 11 (21), 133-142.

Abdullah, A. H., \& Zakaria, E. 2013. Enhancing Students' Level of Geometric Thinking through van Hiele's Phase-Based Learning. Indian Journal of Science and Technology, 6 (5) : 1-15

Agustina, M. L. 2013. Identifikasi Tingkat Metakognisi Siswa Dalam Memecahkan Masalah Matematika Berdasarkan Perbedaan Skor $\quad$ Matematika.
MATHEdunesa, 2 (1) : 1-8

Akbar, Padillah, Abdul Hamid, Martin Bernard, and Asep Ikin Sugandi. 2017. Analisis Kemampuan Pemecahan Masalah Dan Disposisi Matematik Siswa Kelas XI SMA Putra Juang Dalam Materi Peluang. Jurnal Cendekia: Jurnal Pendidikan Matematika, 2(1), 144-153

Aminah, Mimih, and Jozua Sabandar. 2011. The Potency Of Metacognitive Learning To Foster Mathematical Logical Thinking. International Seminar and the Fourth National Conference on Mathematics Education 2011, 345-356

Anggo, Mustamin. 2011. Pelibatan Metakognisi Dalam Pemecahan Masalah Matematika. Edumatica, 1 (1).

Annamma, Subini Ancy. 2015. Whiteness as Property: Innocence and Ability in Teacher Education. Urban Review.

Balcomb, Frances K., and Lou Ann Gerken. 2008. Three-Year-Old Children Can Access Their Own Memory to Guide Responses on a Visual Matching Task. Developmental Science, 11(5), 50-60

Bunce, Diane M., and Kira D. Hutchinson. 1993. The Use of the GALT (Group Assessment of Logical Thinking) as a Predictor of Academic Success in College Chemistry. Journal of Chemical Education, 70(3), 183.

Desoete, Annemie. 2009. Metacognitive Prediction and Evaluation Skills and Mathematical Learning in Third-Grade Students. Educational Research and Evaluation, 15(5), 435-446.

Desoete, Annemie, Herbert Roeyers, and Anne Huylebroeck. 2006. Metacognitive Skills in Belgian Third Grade Children (Age 8 to 9) with and without Mathematical Learning Disabilities. Metacognition and Learning, 1(2), 119-135

Effendi, Leo Adhar. 2012. Pembelajaran Matematika Dengan Metode Penemuan Terbimbing Untuk Meningkatkan Kemampuan Representasi Dan Pemecahan Masalah Matematis Siswa SMP. Jurnal 
Penelitian Pendidikan, 13(2), 1-10

Elstad, Eyvind, and Knut Andreas Christophersen. 2017. Perceptions of Digital Competency among Student Teachers: Contributing to the Development of Student Teachers' Instructional Self-Efficacy in TechnologyRich Classrooms. Education Sciences, 7(1), 27.

Fadiana, M., S. M. Amin, A. Lukito, A. Wardhono, and S. Aishah. 2019. Assessment of Seventh Grade Students' Capacity of Logical Thinking. Jurnal Pendidikan IPA Indonesia, 8(1),75-80.

Fadiana, M., S. M. Amin, A. Lukito, and Warli. 2019. How Concrete Operational Student Generalize the Pattern?: Use Semiotic Perspective. in Journal of Physics: Conference Series.

Fadiana, M. 2015. Math Learning Model That Accommodates Cognitive Style to Build Problem-Solving Skills. Higher Education Studies, 5(4): 86.

Fadiana, M. 2016. Strategi Generalisasi Pola pada Siswa Kelas VII. Prosiding Seminar Nasional Matematika $X$ Universitas Negeri Semarang 2016, 230-240

Hasibuan, Ainul Marhamah, Sahat Saragih, and Zul Amry. 2018. Development of Learning Materials Based on Realistic Mathematics Education to Improve Problem Solving Ability and Student Learning Independence. International Electronic Journal of Mathematics Education, 14(1), 243-252

Kincal, Remzi Y., and Akan Deniz Yazgan. 2010. Investigating the Formal Operational Thinking Skills of 7th and 8th Grade Primary School Students According to Some Variables. Ilkogretim Online, 9 (2)

Larkin, Shirley. 2006. Collaborative Group Work and Individual Development of Metacognition in the Early Years. Research in Science Education, 36(1), 727.

Miles, Matthew B., A. Michael Huberman, and Johnny Saldana. 2014. Qualitative Data Analysis: A Methods Sourcebook. Third Edition.

Minarni, Ani, E. Elvis Napitupulu, and Rahmad Husein. 2016. Mathematical Understanding and Representation Ability of Public Junior High School in North Sumatra. Journal on Mathematics Education, 7(1), 45-58
Nadapdap, Amipa Tri Yanti, and Edi Istiyono. 2017. Developing Physics ProblemSolving Skill Test for Grade X Students of Senior High School. Research and Evaluation in Education, 3(2), 114-123.

Ojose, Bobby. 2015. Applying Piaget's Theory of Cognitive Development to Mathematics Instruction. The Mathematics Educator, 18 (1).

Othman, Mahfudzah, Fazlin Marini Hussain, and Khairunisa Nikman. 2010. Enhancing Logical Thinking among Computer Science Students through Cooperative Learning. Gading Business and Management Journal, 14, 1-10.

Phonapichat, Prathana, Suwimon Wongwanich, and Siridej Sujiva. 2014. An Analysis of Elementary School Students' Difficulties in Mathematical Problem Solving. Procedia - Social and Behavioral Sciences, 116: 3169-3174.

Puadi, Evan Farhan Wahyu, and Muhammad Irfan Habibie. 2018. Implementasi PBL Berbantuan GSP Software Terhadap Peningkatan Kemampuan Pemecahan Masalah Matematik Siswa. IndoMath: Indonesia Mathematics Education, 1(1), 19-26.

Schraw, Gregory. 2010. Measuring SelfRegulation in Computer-Based Learning Environments. Educational Psychologist, 45(4), 258-266.

Setyadi, Danang. 2017. Metacognition Rocess of Students Class X Senior High School in Mathematic Problem Solving. IOSR Journal of Research \& Method in Education.

Siagian, Meryance V., Sahat Saragih, and Bornok Sinaga. 2019. Development of Learning Materials Oriented on Problem-Based Learning Model to Improve Students' Mathematical Problem Solving Ability and Metacognition Ability. International Electronic Journal of Mathematics Education, 14(2), 331-340.

Su, Hui Fang Huang, Frederick A. Ricci, and Mamikon Mnatsakanian. 2016. Mathematical Teaching Strategies: Pathways to Critical Thinking and Metacognition. International Journal of Research in Education and Science, 2(1), 190-200.

Suherman, Erman dkk. 2011. Strategi Pembelajaran Matematika Kontemporer. Bandung: PT Remaja Rosdakarya. 
Mu'jizatin Fadiana dan Andriani

Anargya: Jurnal Pendidikan Matematika, Vol. 4 No.1, April 2021 https://dx.doi.org/10.24176/anargya.v4i1.6067

Surya, Edy, Feria Andriana Putri, and Mukhtar. 2017. Improving Mathematical ProblemSolving Ability and Self-Confidence of High School Students through Contextual Learning Model. Journal on Mathematics Education, 8(1), 85-94

Widodo, Sri Adi, and Turmudi Turmudi. 2017. Guardian Student Thinking Process in
Resolving Issues Divergence. Journal of Education and Learning (EduLearn), 11(4), 432-438

Yenita Roza, and Eliya Astika. 2019. Model Pembelajaran Berbasis Masalah Untuk Meningkatkan Kemampuan Pemecahan Masalah Matematis. Talenta Conference Series: Science and Technology (ST), 2(2). 